\title{
LA PROTECCIÓN DE LOS DERECHOS AL HONOR, INTIMIDAD Y PROPIA IMAGEN DEL MENOR CON SUFICIENTE MADUREZ: ENTRE EL RESPETO A SUS DECISIONES Y LA INTERVENCIÓN DEL MINISTERIO FISCAL
}

\author{
Fuensanta RABADÁn SÁnCHEZ-LAFUENTE \\ Profesora Ayudante Doctora \\ Departamento de Derecho Privado. Área de Derecho Civil \\ Universidad de Cádiz \\ fuensanta.rabadan@uca.es
}

\begin{abstract}
RESUMEN
En virtud del art. 3.1 de la Ley Orgánica 1/1982, de 5 de mayo, cuando los menores tengan suficiente madurez deberán consentir por sí mismos las intromisiones en sus derechos al honor, intimidad y propia imagen. Sin embargo, atendiendo al art. 4 de la Ley Orgánica de Protección Jurídica del Menor, cuando la intromisión tenga lugar en un medio de comunicación seguirá siendo ilegítima, aun consentida por un menor maduro, si se considera contraria a su bonor e intereses, debiendo intervenir en su defensa el Ministerio Fiscal. Esta regulación plantea diversas cuestiones relacionadas con la protección de los derechos al honor, intimidad y propia imagen del menor con suficiente madurez - en particular, sobre la función del fiscal como garante de estos derechos y el papel que se otorga al consentimiento del menorque son objeto de estudio del presente trabajo.
\end{abstract}

Palabras clave: menor, protección, derechos, honor, intimidad, propia imagen, Ministerio Fiscal.

\section{ABSTRACT}

According to 3.1 article of Spanish Basic Law 1/1982, 5 May, in the case of the minor, mature enough, it is up to him/ her to permit intromissions in their right to honour, privacy and personal image. However, according to article 4 of Basic Act for Legal Protection of the Minor, if the intruder is a mass media, it will still be considered illegal, even in the case of consent by a minor yet mentally of age, when considered contrary to his/her honour and interests. In such case the Prosecution Service will take action. Such regulation raises some issues regarding the right to honour, privacy and personal image of the minor, yet mentally of age, particularly on the role of the public prosecutor as guarantee of such rights and the role of the minor's consent, which we study in this piece of work.

Keywords: Minor, protection, rights, honour, privacy, personal image, Prosecution Service. 


\section{ZUSAMMENFASSUNG}

Ausgebend vom Art. 3.1 des Spanischen Verfassungsgesetzes 1/1982, vom 5. Mai, sollten die Minderjäbrigen mit ausreichender Reife über Eingriffe in ihr Recht auf Ehre, ibre Privatsphäre und ibr eigenes Bild selbst entscheiden können. Jedoch, wenn man dem Art. 4 des Spanischen Verfassungsgesetzes zum Schutz der Minderjäbrigen folgt, ist der Eingriff dann gesetzeswidrig und die Staatsanwalt muss einschreiten, wenn dieser in einem Kommunikationsmedium erfolgt und seine Ehre und seine Interessen verletzt werden; auch dann, wenn der Eingriff mit Zustimmung des Minderjährigen erfolgt und dieser mit ausreichender Reife ausgestattet ist. Diese Gesetzesregelung wirft verschiedene Fragen auf, die mit dem Schutz des Rechts auf Ehre, der Privatsphäre und des eigenen Bildes des Minderjährigen mit ausreichender Reife einher gehen-insbesondere zur Funktion des Staatsanwalts als dem Garanten dieser Rechte sowie der Rolle, die man der Zustimmung des Minderjäbrigen zuweist. Diese beiden Fragen sind der Gegenstand der vorliegenden Arbeit.

Schlüsselwörter: Minderjährige, Schutz, Rechte, Ehre, Privatspähre, eigenes Bild, Staatsanwaltschaft.

SUMARIO: I. INTRODUCCIÓN.-II. LOS DERECHOS AL HONOR, INTIMIDAD PERSONAL Y FAMILIAR, Y PROPIA IMAGEN.-III. EL CONSENTIMIENTO DEL MENOR MADURO EN EL EJERCICIO DE SUS DERECHOS AL HONOR, INTIMIDAD Y PROPIA IMAGEN.-IV. ANÁLISIS DEL ART. 4.3 LOPJM.-V. LA INTERVENCIÓN DEL MINISTERIO FISCAL.VI. CONCLUSIONES.-VII. BIBLIOGRAFÍA.

\section{INTRODUCCIÓN}

La presencia de menores en los medios de comunicación - concursos televisivos, entrevistas en prensa, etc. - en los que se utiliza su imagen o se dan a conocer aspectos de su intimidad es una realidad habitual en nuestros días. Siguiendo lo dispuesto en el art. 3 de la Ley Orgánica 1/1982, de 5 de mayo, de Protección Civil del Derecho al Honor, a la Intimidad Personal y Familiar, y a la Propia Imagen (LO 1/1982), los menores deberán consentir por sí mismos esa intromisión en sus derechos, si sus condiciones de madurez así lo permiten, o, en caso contrario, si el menor no fuese lo suficientemente maduro, deberán consentir sus representantes legales.

Sin embargo, el consentimiento otorgado por el propio menor o sus representantes legales no legitima una intromisión en sus derechos al honor, intimidad y propia imagen, cuando la utilización de su imagen o nombre en los medios de comunicación pudiera implicar menoscabo de su honra o reputación, o fuese contraria a sus intereses, de acuerdo con el art. 4.3 de la Ley Orgánica 1/1996, de 15 de enero, de Protección Jurídica del Menor, de 
modificación parcial del Código Civil y de la Ley de Enjuiciamiento Civil (LOPJM), dándose en estos casos una vulneración del honor, intimidad o propia imagen del menor, y debiendo, además, intervenir el Ministerio Fiscal en defensa y protección de los menores — art. 4.2 y 4.4 LOPJM-.

En este sentido, la Sentencia de la Audiencia Provincial de Sevilla (Sección 2. $\left.{ }^{a}\right)$ de 6 de febrero de 2013 desestimó el recurso de apelación presentado contra la sentencia del Juzgado de Primera Instancia de Sevilla de 11 de enero de 2011, que resolvió que se había producido una intromisión ilegítima en los derechos a la intimidad y propia imagen de una menor, pues, conforme al art. 4.3 LOPJM, era contraria a los intereses de la menor su participación en varios programas de televisión de ámbito nacional, en los que se le interrogaba sobre su vida privada al hilo de unos acontecimientos de gran impacto social - el asesinato de una joven-, aunque dicha participación había tenido lugar con el consentimiento de la menor. En el recurso de apelación que resuelve la Audiencia Provincial de Sevilla el Ministerio Fiscal era parte apelada, pues había sido éste quien presentó, en primera instancia, la demanda contra los responsables de la intromisión - las personas jurídicas que gestionaban la cadena y programas de televisión en los que apareció la menor-, cumpliendo así con sus obligaciones de defensa y protección de los menores.

Tras la mencionada Sentencia de la Audiencia Provincial de Sevilla ha vuelto a suscitarse el debate en torno a los siguientes aspectos: la compatibilidad entre la LO 1/1982 y el art. 4 LOPJM; el valor que se confiere al consentimiento de los menores en el ejercicio de sus derechos al honor, intimidad y propia imagen, y el posible «choque», en el ámbito de protección de estos derechos, entre las decisiones del menor y la intervención del Ministerio Fiscal. Estas cuestiones constituyen el objeto de estudio de nuestro trabajo.

\section{LOS DERECHOS AL HONOR, INTIMIDAD PERSONAL Y FAMILIAR, Y PROPIA IMAGEN}

Los derechos al honor, intimidad personal y familiar, y propia imagen se garantizan en el art. 18.1 CE, desarrollándose la protección civil de estos derechos en la LO 1/1982, y reforzándose para los menores en el art. 4 LOPJM estas garantías previstas por la LO 1/1982 ${ }^{1}$.

\footnotetext{
${ }^{1}$ Véase Exposición de Motivos de la LOPJM.
} 
Si bien la protección de los derechos al honor, intimidad personal y familiar, y propia imagen se lleva a cabo de forma conjunta tanto en el art. 18.1 CE, como en la LO 1/1982 y en la LOPJM, jurisprudencia y doctrina coinciden en afirmar que se trata de tres derechos distintos, cada uno con su propio contenido ${ }^{2}$.

Así, por honor se entiende «la dignidad personal reflejada en la consideración de los demás y en el sentimiento de la propia persona» ${ }^{3}$. Es decir, el honor presenta una vertiente externa (la fama, reputación o estimación que los demás hacen de nuestra dignidad) y una vertiente interna o subjetiva (el sentimiento o estimación que la persona tiene de su propia dignidad). Esto conlleva que al titular del derecho al honor se le proteja frente a aquellas conductas que lesionan su dignidad menoscabando su fama, o bien atentando contra su propia estimación ${ }^{4}$.

La intimidad hace referencia a la esfera o ámbito donde se desenvuelve la vida de una persona (o familia) que queda reservado frente a los demás. Por tanto, el derecho a la intimidad conllevaría para su titular la facultad de crear y mantener esa esfera reservada en la que no pueden entrometerse los demás, y de decidir qué datos, hechos o vivencias de los que conforman esa esfera personal (o familiar) pueden divulgarse o darse a conocer a otros ${ }^{5}$.

2 Véanse SSTC 81/2001, de 26 de marzo; 139/2001, de 18 de junio, y 83/2002, de 22 de abril, entre otras. Véanse también X. O'CALlaghan MuÑoz, «Personalidad y derechos de la personalidad (honor, intimidad e imagen) del menor según la Ley de Protección del Menor», La Ley: Revista jurídica española de doctrina, jurisprudencia y bibliografía, núm. 4 (1996), p. 1249; J. GARBERí Llobregat, Los procesos civiles de protección del honor, la intimidad y la propia imagen, Barcelona, Bosch, 2007, pp. 87 y 88; P. GRIMALT SERVERA, La protección civil de los derechos al honor, a la intimidad y a la propia imagen, Madrid, Iustel, 2007, p. 26; J. L. Lacruz Berdejo et al., Elementos de Derecho Civil. I. Parte General, vol. II, Personas, Madrid, Dykinson, 2010, pp. 91 y 94; M. CAstilla BAREa, Las intromisiones legítimas en el derecho a la propia imagen, Cizur Menor, Aranzadi, 2011, pp. 71 y 72; L. DíEz-PICAzo y A. Gullón, Sistema de Derecho Civil, vol. I, Madrid, Tecnos, 2012, p. 341, y A. Paños PÉREZ, «El interés del menor como criterio para determinar la ilegitimidad de la intromisión en los derechos del honor, la intimidad y la propia imagen», Revista Actualidad Civil, núm. 8 (2012), p. 817.

3 Véanse X. O'Callaghan MuÑoz, «Personalidad y derechos de la personalidad...», op. cit., p. 1249, y J. L. Lacruz Berdejo et al., Elementos de Derecho Civil..., op. cit., p. 91.

${ }^{4}$ Véanse STC 127/2003, de 30 de junio, y SSTS de 9 de octubre de 1997 y de 23 de marzo de 1987, entre otras. Véanse también X. O’CALlaghan Muñoz, «Personalidad y derechos de la personalidad...», op. cit., p. 1249; M. Albaladejo, Derecho Civil. I. Introducción y Parte General, Madrid, Edisofer, 2009, p. 460; J. L. Lacruz Berdejo et al., Elementos de Derecho Civil..., op. cit., p. 91, y L. Díez-Picazo y A. Gullón, Sistema de Derecho Civil, op. cit., pp. 340 y 349.

5 Como ejemplo véanse SSTC 115/2000, de 5 de mayo; 83/2002, de 22 de abril, y 99/2002, de 6 de mayo. Véanse también X. O’CALlaghan Muñoz, «Personalidad y derechos de la personalidad...», op. cit., p. 1249; J. GaRBERí Llobregat, Los procesos civiles de 
Por último, la imagen se refiere a la figura, aspecto o rasgos físicos de una persona que la hacen reconocible, y puede ser objeto de captación o reproducción por fotografía, filme, pintura, etc. El derecho a la propia imagen implicaría para su titular poder disponer de la reproducción de su imagen o aspecto, decidiendo si permite o prohíbe a otros esa reproducción, y decidiendo el uso que se le va a dar a esas representaciones de su imagen ${ }^{6}$.

El contenido de estos derechos se ha delimitado por la jurisprudencia del Tribunal Constitucional y la del Tribunal Supremo ante la ausencia de definiciones legales ${ }^{7}$.

Por otro lado, la LO 1/1982 dispone, en su art. 1, que los derechos al honor, a la intimidad personal y familiar, y a la propia imagen serán protegidos civilmente frente a todo género de intromisiones ilegítimas, y recoge en el art. 7 un elenco de actuaciones o conductas que tendrán la consideración de intromisiones ilegítimas, si bien no diferencia cuándo resulta afectado uno u otro derecho ${ }^{8}$. Este tratamiento unitario de las intromisiones ilegítimas no significa que la vulneración del derecho al honor, a la intimidad y a la propia imagen se produzca siempre de forma simultánea, pues, como hemos señalado anteriormente, cada derecho tiene un

protección del honor..., op. cit., p. 140; M. Albaladejo, Derecho Civil..., op. cit., pp. 463 y 464; J. L. Lacruz Berdejo et al., Elementos de Derecho Civil..., op. cit., pp. 92 y 93; C. LaSARTE, Principios de Derecho Civil, t. I, Parte General y derecho de la persona, Madrid, Marcial Pons, 2010, p. 169, y L. Díez-PiCAzo y A. Gullón, Sistema de Derecho Civil, op. cit., pp. 340 y 341.

6 Véanse las SSTC 86/2001, de 26 de marzo; 139/2001, de 18 de junio; 158/2009, de 29 de junio, y STS de 11 de abril de 1987. La STC 117/1994, de 25 de abril, maneja un concepto amplio del derecho a la imagen que incluye la voz y el nombre. También la Ley Orgánica 1/1982 señala como intromisión ilegítima «la utilización del nombre, de la voz o de la imagen de una persona para fines publicitarios, comerciales o de naturaleza análoga» (art. 7.6). Véanse también M. Albaladejo, Derecho Civil..., op. cit., pp. 466-468; J. L. Lacruz BerdeJo et al., Elementos de Derecho Civil..., op. cit., pp. 93 y 94; M. Castilla Barea, Las intromisiones legitimas..., op. cit., pp. 36-52, y L. DíEZ-PicAZO y A. Gullón, Sistema de Derecho Civil, op. cit., p. 341.

7 Véanse X. O'Callaghan Muñoz, «Personalidad y derechos de la personalidad...», op. cit., p. 1249; A. L. CABEZUelo Arenas, Derecho a la intimidad, Valencia, Tirant lo Blanch, 1998, pp. 15, 16 y 425; P. Grimalt Servera, La protección civil de los derechos al honor..., op. cit., pp. 26 y 27; J. L. LaCruz Berdejo et al., Elementos de Derecho Civil..., op. cit., p. 94, y M. Castilla Barea, Las intromisiones legítimas..., op. cit., pp. 31, 32 y 70.

${ }^{8}$ Para la mayoría de la doctrina, este listado de intromisiones ilegítimas no ha de considerarse un numerus clausus, ya que, en la práctica, pueden darse conductas o actuaciones no incluidas en el art. 7 pero que constituyen una lesión a estos derechos desde la perspectiva del art. 18 CE. En este sentido véanse A. L. Cabezuelo Arenas, Derecho a la intimidad, op. cit., p. 108; P. Grimalt Servera, La protección civil de los derechos al honor..., op. cit., pp. 63 y 64; C. Lasarte, Principios de Derecho Civil, op. cit., p. 170, y L. Díez-Picazo y A. Gullón, Sistema de Derecho Civil, op. cit., p. 351. 
contenido propio y distinto, pudiendo darse la infracción de uno sólo de estos derechos?.

Por el contrario, la LO 1/1982 dispone en el art. 2.2 que «no se apreciará la existencia de intromisión ilegítima en el ámbito protegido cuando estuviere expresamente autorizada por ley o cuando el titular del derecho hubiese otorgado al efecto su consentimiento expreso», y recoge en el art. 8 una serie de excepciones a las intromisiones ilegítimas, señalándose en el apartado $1 .^{\circ}$ que «no se reputarán, con carácter general, intromisiones ilegítimas las actuaciones autorizadas o acordadas por la autoridad competente de acuerdo con la ley, ni cuando predomine un interés histórico, científico o cultural relevante».

\section{EL CONSENTIMIENTO DEL MENOR MADURO EN EL EJERCICIO DE SUS DERECHOS AL HONOR, INTIMIDAD Y PROPIA IMAGEN}

Si atendemos a lo dispuesto en el art. 2.2 de la LO 1/1982 no cabe apreciar la existencia de intromisión ilegítima en el ámbito protegido de los derechos al honor ${ }^{10}$, intimidad y propia imagen cuando el titular de los mismos hubiera otorgado al efecto su consentimiento expreso ${ }^{11}$. Así, el consentimiento del titular elimina el carácter ilegítimo de la intromisión en los derechos al honor, intimidad y propia imagen ${ }^{12}$.

9 Véanse STC de 83/2002, de 22 de abril, y ATC 28/2004, de 6 de febrero. Véanse también X. O'Callaghan Muñoz, «Personalidad y derechos de la personalidad...», op. cit., p. 1249; P. GRImalt SeRvera, La protección civil de los derechos al honor..., op. cit., p. 26, y M. Castilla Barea, Las intromisiones legítimas..., op. cit., pp. 71 y 72.

${ }^{10} \mathrm{La}$ disponibilidad del derecho al honor es objeto de discusión en la doctrina. Para algunos autores su conexión con la dignidad no permite a su titular disponer y, por tanto, tampoco consentir una intromisión en el mismo. Otros autores sí sostienen esa posibilidad, siempre que no se despoje al honor de su núcleo o contenido esencial. Véase A. DE LAMA Aymá, La protección de los derechos de la personalidad del menor de edad, Valencia, Tirant lo Blanch, 2006, pp. 232 y ss.

${ }^{11}$ La mayor parte de la jurisprudencia y de la doctrina llevan a cabo una interpretación amplia del término «expreso» que permitiría incluir el consentimiento tácito cuando esa voluntad se deduce de actos inequívocos del titular, pero que excluiría el consentimiento presunto. Véanse las SSTS de 27 de junio de 1996, de 25 de enero de 2002, de 22 de febrero de 2006 y de 25 de febrero de 2009. En doctrina véanse P. GRIMALT SERvera, La protección civil de los derechos al honor..., op. cit., p. 105; J. L. LACRUZ BERDEJO et al., Elementos de Derecho Civil..., op. cit., p. 100, y M. CAstilla BAREA, Las intromisiones legitimas..., op. cit., pp. 172 y ss.

12 Véanse STC 139/2001, de 18 de junio, y STS de 25 de febrero de 2009. Véanse también M. Castilla Barea, Las intromisiones legítimas..., op. cit., pp. 115 y ss., y L. Díez-PicA- 
En el caso de los menores ${ }^{13}$, de acuerdo con el art. 3.1 de la LO 1/1982, este consentimiento legitimador de la intromisión «deberá prestarse por ellos mismos si sus condiciones de madurez lo permiten, de acuerdo con la legislación civil». Es decir, siempre que el menor sea lo suficientemente maduro se quiere que consienta éste, en lugar de sus representantes legales. Esta norma debe ponerse en relación con el art. 162 CC, el cual dispone que «los padres que ostenten la patria potestad tienen la representación legal de sus hijos menores no emancipados», y a continuación exceptúa de esta representación legal «los actos relativos a los derechos de la personalidad que el hijo, de acuerdo con su madurez, pueda ejercitar por sí mismo» ${ }^{14}$. Por tanto, el art. 3.1 de la LO 1/1982 reitera lo preceptuado en el art. 162 CC, pero refiriéndose a unos concretos derechos de la personalidad, como son el honor, la intimidad y la propia imagen, y a un acto concreto relativo a estos derechos, como es el consentimiento a las intromisiones ${ }^{15}$.

Cuando los menores no presentasen suficiente madurez, el consentimiento legitimador de la intromisión habrá de otorgarse por sus representantes legales, por escrito y poniéndolo previamente en conocimiento del

zo y A. Gullón, Sistema de Derecho Civil, op. cit., p. 348. Para Cabezuelo Arenas el consentimiento impide que pueda hablarse de intromisión. Véase A. L. CABEZuelo Arenas, Derecho a la intimidad, op. cit., pp. 302, 303 y 435.

${ }_{13}$ Nos referimos a menores no emancipados, pues los emancipados se equiparan a los mayores de edad en el ámbito personal y no les resultaría aplicable el art. 3 de la LO 1/1982. Véanse P. Grimalt Servera, La protección civil de los derechos al honor..., op. cit., p. 111, y M. Castilla Barea, Las intromisiones legítimas..., op. cit., p. 127. Véase también la Instrucción de la Fiscalía General del Estado núm. 2/2006, de 15 de marzo, sobre el fiscal y la protección del derecho al honor, intimidad y propia imagen de los menores (apartado 2).

${ }^{14} \mathrm{La}$ actual redacción del art. 162.1. ${ }^{\circ} \mathrm{CC}$ es resultado de la recién promulgada Ley 26/2015, de 28 de julio, de modificación del sistema de protección a la infancia y a la adolescencia, que además ha añadido a este punto primero el siguiente inciso: «No obstante, los responsables parentales intervendrán en estos casos en virtud de sus deberes de cuidado y asistencia».

15 Véanse X. O'Callaghan Muñoz, «Personalidad y derechos de la personalidad...», op. cit., p. 1250: A. DE LAMA Aymá, La protección de los derechos de la personalidad..., op. cit., p. 171; J. L. Lacruz Berdejo et al., Elementos de Derecho Civil..., op. cit., p. 101; M. CasTILla Barea, Las intromisiones legítimas..., op. cit., p. 130; M. J. SANTos Morón, «Menores y derechos de la personalidad. La autonomía del menor», Anuario de la Facultad de Derecho de la Universidad Autónoma de Madrid, núm. 15 (2011), p. 77, y A. PAÑos PéreZ, «El interés del menor como criterio...», op. cit., p. 819. Estos autores resaltaban la concordancia entre el art. 3.1 de la LO 1/982 y el art. 162.1. ${ }^{\circ} \mathrm{CC}$ en su antigua redacción, que exceptuaba de la representación legal de los padres a «los actos relativos a derechos de la personalidad u otros que el hijo, de acuerdo con las leyes y sus condiciones de madurez, pueda realizar por sí mismo». No obstante, sus consideraciones son trasladables a la relación entre el art. 3.1 y el vigente art. 162.1. 
Ministerio Fiscal, resolviendo finalmente el juez si el fiscal se opusiera en el plazo de ocho días —art. 3.2 de la LO 1/1982—.

La madurez del menor es, por tanto, la primera circunstancia que habrá de tenerse en cuenta para concluir si el consentimiento al que alude el art. 3 de la LO 1/1982 debe prestarse por el propio menor en ejercicio de sus derechos de la personalidad o, por el contrario, debe otorgarse por los representantes legales del menor.

A este respecto, la LO 1/1982 no define qué se entiende por «condiciones de madurez», sino que, como ya hemos mencionado, su art. 3.1 se remite a la legislación civil. Sin embargo, ni el Código Civil ni la LOPJM, que también regula estos derechos, definen este concepto. No obstante, atendiendo a lo dispuesto por la doctrina, entendemos que el menor es lo suficientemente maduro cuando es capaz de comprender las consecuencias de sus actos y decidir por sí mismo ${ }^{16}$.

Tampoco contienen las normas mencionadas - CC, LO 1/1982 y LOPJM - criterios que permitan concluir cuándo el menor es maduro para consentir una intromisión en los derechos al honor, intimidad y propia imagen, ni se fija en las mismas una edad a partir de la cual presumir que el menor ha adquirido la madurez necesaria para prestar por sí este consentimiento ${ }^{17}$. Por ello, en el ámbito que nos ocupa, las condiciones de madurez del menor habrán de valorarse caso por caso.

Así se pone de manifiesto en la Instrucción de la Fiscalía General del Estado núm. 2/2006, de 15 de marzo, sobre el fiscal y la protección del derecho al honor, intimidad y propia imagen de los menores (apartado 3.3), que señala: «El Código Civil no contiene un precepto específico que defina con carácter general cuándo debe considerarse maduro al menor [...] Ello

16 Véanse X. O'Callaghan Muñoz, «Personalidad y derechos de la personalidad...», op. cit., p. 1248; J. L. Lacruz Berdejo et al., Elementos de Derecho Civil..., op. cit., p. 101; M. C. GaRCía GARnICA, El ejercicio de los derechos de la personalidad del menor no emancipado, Cizur Menor, Aranzadi, 2004, p. 198, y M. CAstilla Barea, Las intromisiones legitimas..., op. cit., p. 133. Asimismo, véase la Observación núm. 12, de 12 de junio de 2009, del Comité de Naciones Unidas de Derechos del Niño, sobre el derecho del niño a ser escuchado, que define madurez como «la capacidad de comprender y evaluar las consecuencias de un asunto determinado».

${ }_{17}$ Por el contrario, la LOPJM sí contiene criterios para concluir la madurez del menor en el ámbito del derecho a la audiencia, y así, en la regulación del mismo que lleva a cabo en el art. 9.2, dispone «se garantizará que el menor, cuando tenga suficiente madurez, pueda ejercitar este derecho por sí mismo o a través de la persona que designe para que le represente. La madurez habrá de valorarse por personal especializado, teniendo en cuenta tanto el desarrollo evolutivo del menor como su capacidad para comprender y evaluar el asunto concreto a tratar en cada caso. Se considera, en todo caso, que tiene suficiente madurez cuando tenga doce años cumplidos». 
lleva a la necesidad de integrar este concepto jurídico indeterminado valorando todas las circunstancias concurrentes en el caso, partiendo de que la capacidad general de los menores no emancipados es variable o flexible en función de la edad, del desarrollo emocional, intelectivo y volitivo concreto del menor, y de la complejidad del acto de que se trate».

Por tanto, el menor es lo suficientemente maduro cuando es capaz de comprender las consecuencias de sus actos y decidir por sí mismo, lo que, traducido al ámbito que nos ocupa, implica que ha de ser capaz de comprender la trascendencia que tiene consentir una determinada intromisión en sus derechos, y ello exige atender al acto o intromisión concreta que el menor haya de consentir, pues no es lo mismo que el menor acepte participar en un programa de televisión con finalidad educativa o de entretenimiento dirigido a niños o jóvenes de su edad, que el menor participe en un programa diseñado para una audiencia adulta, como ocurre en el supuesto resuelto por la anteriormente citada Sentencia de la Audiencia Provincial de Sevilla (Sección 2. ${ }^{a}$ ) de 6 de febrero de 2013. Asimismo, concluir esa capacidad de entendimiento exige atender al desarrollo madurativo del menor, que es diferente en cada niño y depende de múltiples factores — biológicos, sociales, familiares, educativos, etc.-.

En este sentido, consideramos acertado que, en el caso del consentimiento a las intromisiones al derecho al honor, intimidad y propia imagen, el legislador haya optado por no fijar una edad concreta a partir de la cual presumir que el menor tiene madurez suficiente ${ }^{18}$, pues el menor será lo suficientemente maduro cuando sea capaz de comprender las consecuencias que tiene consentir una determinada intromisión, y esto, reiteramos, dependerá de aquello que se esté consintiendo en cada caso concreto - un programa de niños o de adultos, por ejemplo- - y del desarrollo personal del menor ${ }^{19}$.

${ }_{18}$ A este respecto, De la Rosa opina que no deben darse reglas fijas para determinar una edad a partir de la cual deba considerarse al menor con «madurez» suficiente para consentir una intromisión, sino que éste es un concepto que debe integrarse valorando las circunstancias concurrentes en cada caso. No obstante, el autor parece inclinarse finalmente por la presunción de madurez a partir de los dieciséis años. Véase J. M. DE LA Rosa CoRTina, «El derecho al honor, intimidad y propia imagen de los menores. Perspectivas en Derecho civil, penal y en reforma de menores», Revista del Poder Judicial, núm. 72 (2003), pp. 24 y 25. Asimismo, véase M. J. SAnTos Morón, «Menores y derechos de la personalidad...», op. cit., pp. 73 y 74. Por el contrario, otros autores se inclinan por el criterio de los doce años cumplidos como edad a partir de la cual presumir suficiente madurez para consentir una intromisión. Véanse A. De Lama Aymá, La protección de los derechos de la personalidad..., op. cit., pp. 150, 151, 284 y 285, y A. PAÑos PÉREZ, «El interés del menor como criterio...», op. cit., p. 820.

19 En este sentido, Santos Morón señala que «ni todos los menores tienen la misma madurez, ni todos los actos de intromisión en los derechos a la intimidad tienen el mismo 
En definitiva, el art. 3.1 de la LO 1/982, al disponer que el consentimiento a las intromisiones al honor, intimidad y propia imagen del menor «deberá prestarse por ellos mismos si sus condiciones de madurez lo permiten», está reconociendo que el menor puede tomar sus propias decisiones a este respecto, es decir, está reconociendo al menor un ámbito de autonomía que habrá de respetarse si queremos proteger adecuadamente sus intereses $^{20}$. No obstante, el respeto a la autonomía del menor y a sus decisiones no debe ser malentendido y equipararse con la concesión al mismo de una libertad ilimitada, ya que, atendiendo al art. 9 bis LOPJM, «los menores, de acuerdo a su edad y madurez, deberán asumir y cumplir los deberes, obligaciones y responsabilidades inherentes o consecuentes a la titularidad y al ejercicio de los derechos que tienen reconocidos», y conforme al art. 155 CC, «deben obedecer a sus padres mientras permanezcan bajo su potestad y respetarles siempre». Por el contrario, el respeto a su autonomía implica reconocer su individualidad, tomar conciencia de que cada niño o adolescente tiene una forma propia de ser, de sentir y de pensar que no tiene por qué coincidir con la de sus padres; por ello, el art. 2.2.b) LOPJM, a efectos de la interpretación y aplicación en cada caso del interés superior del menor, señala que se tendrán en cuenta «los deseos, sentimientos y opiniones del menor, así como su derecho a participar progresivamente, en función de su edad, madurez, desarrollo y evolución personal, en el proceso de determinación de su interés superior».

\section{ANÁLISIS DEL ART. 4.3 LOPJM}

Cuando nos referimos a mayores de edad, el consentimiento prestado por el titular de los derechos al honor, intimidad y propia imagen elimina el carácter ilegítimo de una intromisión en estos derechos, como hemos

alcance», y pone como ejemplo la STS de 19 de julio de 2000, que consideró válido el consentimiento prestado por un joven de dieciséis años para participar en un concurso televisivo en el que perdía una prenda de vestir por cada pregunta formulada que no acerta$\mathrm{ba}$, argumentando que a los dieciséis años el menor era lo suficientemente maduro para conocer la fuerte carga erótica del programa. A este respecto sostiene la autora que la solución «no hubiese sido la misma si el menor hubiese contado con sólo doce años», y añade que «distinta sería la situación si un menor, de doce años, participa en un desfile de modelos organizado con fines benéficos en su colegio, donde se le toman fotos que aparecen luego en prensa». Cfr. M. J. SAntos Morón, «Menores y derechos de la personalidad...», op. cit., p. 73.

${ }^{20}$ Como señala la LOPJM en su Exposición de Motivos: «La mejor forma de garantizar social y jurídicamente la protección a la infancia es promover su autonomía como sujetos». 
expuesto anteriormente. Conforme al art. 3.1 de la LO 1/1982, el tratamiento que se le da al consentimiento del menor maduro es análogo al de un mayor de edad ${ }^{21}$; sin embargo, la regulación de los derechos al honor, intimidad y propia imagen de los menores establecida en la LOPJM introduce una particularidad o diferencia, ya que, en virtud del art. 4.3, «se considera intromisión ilegítima en el derecho al honor, a la intimidad personal y familiar, y a la propia imagen del menor, cualquier utilización de su imagen o su nombre en los medios de comunicación que pueda implicar menoscabo de su honra o reputación, o que sea contraria a sus intereses, incluso si consta el consentimiento del menor o de sus representantes legales». Por tanto, el consentimiento del menor maduro ${ }^{22}$ no basta para legitimar una intromisión en sus derechos cuando se dan los presupuestos del apartado 3. ${ }^{\circ}$ del art. 4 LOPJM.

Siguiendo al art. 4.3 LOPJM existirá una intromisión ilegítima en el derecho al honor, intimidad y propia imagen del menor cuando la utilización de su imagen o nombre en los medios de comunicación pueda implicar menoscabo de su honra o reputación o sea contraria a sus intereses, aun cuando el menor lo haya consentido. Hay que tener en cuenta que, pese a la referencia conjunta al honor, intimidad y propia imagen que realiza el art. 4.3 LOPJM, la vulneración de estos derechos no tiene por qué darse siempre de forma simultánea, ya que, al tratarse de derechos distintos, un supuesto determinado puede implicar la infracción de uno solo de estos derechos ${ }^{23}$.

Asimismo, al referir el art. 4.3 LOPJM supuestos de intromisiones ilegítimas en el derecho al honor, intimidad y propia imagen del menor es necesario poner en relación este artículo con el art. 7 de la LO 1/1982, que igualmente define una serie de conductas como intromisiones ilegítimas contra estos derechos, y analizar la compatibilidad entre ambos preceptos; en concreto, si el art. 4.3 LOPJM desplaza (o no) la aplicación del art. 7 de la LO 1/1982 para el caso de menores. Teniendo en cuenta que la finalidad de la LOPJM es reforzar la protección que la LO 1/1982 dispensa al menor, el art. 4.3 LOPJM no desplaza la aplicación del art. 7 de

${ }^{21}$ Véase M. Castilla Barea, Las intromisiones legitimas..., op. cit., p. 204.

22 De Lama Aymá explica que el art. 4.3, cuando dice «incluso si consta el consentimiento del menor», se está refiriendo a aquellos supuestos en los que el menor tiene suficiente capacidad natural para consentir por sí mismo la intromisión, en oposición a aquellos casos en los que no tiene suficiente madurez y consienten sus representantes legales. Véase A. De Lama Aymá, La protección de los derechos de la personalidad..., op. cit., p. 171.

${ }^{23}$ Véase X. O’Callaghan Muñoz, «Personalidad y derechos de la personalidad...», op. cit., p. 1249. 
la LO 1/982, pues, de sostenerse lo contrario, sólo serían intromisiones ilegítimas los supuestos referidos en el art. 4.3, resultando el ámbito de protección de estos derechos considerablemente reducido para el menor, en contra de la propia finalidad de la LOPJM ${ }^{24}$. Por tanto, fuera de los casos del art. 4.3 LOPJM caben intromisiones ilegítimas; así, cuando alguna de las actuaciones del art. 7 de la LO 1/1982 tiene lugar sin la aquiescencia del menor maduro, nos hallaremos ante una intromisión que ataca a su honor, intimidad o propia imagen ${ }^{25}$.

En consecuencia, debemos entender que cuando el art. 4.3 LOPJM habla de intromisiones ilegítimas en el derecho al honor, intimidad y propia imagen del menor, no excluye el elenco de intromisiones ilegítimas contenido en el art. 7 de la LO 1/1982, es más, considero que la aplicación del art. 4.3 LOPJM partirá, casi siempre, de alguno de estos supuestos contemplados en el art. 7 de la LO 1/1982 26. Es decir, nos encontraremos ante alguna de las actuaciones definidas como intromisión ilegítima contra el honor, intimidad o propia imagen por el art. 7 de la LO 1/1982, que al haber sido consentida por el menor titular se «convertiría» en legítima conforme a los arts. 2 y 3.1 de la LO 1/1982, pero que, aun consentida por el menor titular, seguirá siendo ilegítima al concurrir los presupuestos del art. 4.3 LOPJM.

Así, por ejemplo, el art. 7 define en su apartado 3 como intromisión ilegítima «la divulgación de hechos relativos a la vida privada de una persona o familia que afecten a su reputación y buen nombre», y en el apartado 6 «la utilización del nombre, de la voz o de la imagen de una persona para fines publicitarios, comerciales o de naturaleza análoga». Tratándose de un menor lo suficientemente maduro para consentir por sí mismo, si con su aquiescencia se revelan datos de su intimidad personal en una entrevista en prensa o se utiliza su imagen en el curso de un programa televisivo no se apreciará la existencia de intromisión ilegítima en la intimidad o en la propia imagen, ya que el titular del derecho ha otorgado al efecto su con-

${ }^{24}$ Cfr. M. C. García Garnica, El ejercicio de los derechos de la personalidad..., op. cit., p. 208. En sentido similar véase L. Dízz-PiCazo y A. Gullón, Sistema de Derecho Civil, op. cit., p. 343.

${ }^{25}$ En sentido similar véase L. DíEz-Picazo y A. Gullón, Sistema de Derecho Civil, op. cit., p. 344.

${ }^{26}$ En sentido similar véase A. DE LAMA AyMÁ, La protección de los derechos de la personalidad..., op. cit., p. 254. Por otro lado, sostenemos que el art. 4.3 LOPJM partirá «casi siempre» de alguno de los supuestos recogidos en el art. 7 de la LO 1/1982, pues, según hemos estudiado, el listado que contiene este precepto no es un numerus clausus, por lo que caben actuaciones contrarias a estos derechos que no estén incluidas en el art. 7. 
sentimiento —arts. 2 y 3.1 de la LO 1/1982—. Sin embargo, si estas mismas hipótesis pudieran implicar menoscabo de su honra o reputación o ser contrarias a sus intereses —art. 4.3 LOPJM — las actuaciones se considerarían ilegítimas.

En este sentido, debemos entender que el art. 4.3 LOPJM no constituye un supuesto de intromisión ilegítima específico o distinto de los contemplados en el art. 7 de la LO 1/1982, sino que, con el propósito de reforzar la protección de los derechos al honor, intimidad y propia imagen del menor, lo que hace el mencionado art. 4.3 es concretar una serie de circunstancias en las cuales el consentimiento del menor maduro carece de eficacia, y por ello la intromisión sigue siendo ilegítima. El art. 4.3 LOPJM excluye, por tanto, la eficacia del consentimiento del menor del art. 3.1 de la LO 1/1982 como elemento legitimador de la intromisión ${ }^{27}$. Ahora bien, no lo excluye con carácter general, sino sólo cuando concurren las circunstancias recogidas en el propio art. 4.3, esto es, cuando la utilización de su imagen o su nombre en los medios de comunicación pueda implicar menoscabo de su bonra o reputación o sea contraria a sus intereses.

Continuando con el análisis de los presupuestos del art. 4.3 LOPJM, éste señala la utilización de la imagen o nombre del menor en los medios de comunicación. La imagen y el nombre conllevan la identificación del menor, que es presupuesto necesario para que pueda apreciarse la existencia de una intromisión ilegítima, si bien la identidad del menor se podrá dar a conocer en el medio de comunicación también a través de otras imágenes o datos.

Por ello, con la utilización de la imagen o nombre del menor el art. 4.3 se refiere a toda utilización de imágenes o datos (entre los que se incluye el nombre) que permita identificar o dar a conocer la identidad del menor en el medio de comunicación ${ }^{28}$. Es decir, no sólo fotografías, vídeos, etc., donde aparezca el menor de forma reconocible, sino también el uso de

${ }^{27}$ Como señala O'Callaghan Muñoz, la especialidad que el art. 4.3 LOPJM presenta respecto a la LO 1/1982 se halla en su último inciso, al disponer la ineficacia del consentimiento que pueda dar el menor o sus representantes legales. De no darse esta especialidad, esta norma sería una mera redundancia de la LO 1/1982. Cfr. X. O’CALlaghan Muñoz, «Personalidad y derechos de la personalidad...», op. cit., p. 1249. También véanse L. Díez-PiCAzo y A. Gullón, Sistema de Derecho Civil, op. cit., p. 344; M. C. García GARnica, El ejercicio de los derechos de la personalidad..., op. cit., pp. 209 y 210; M. NAVARRO MicheL, «Los derechos a la intimidad y propia imagen del menor de edad. Algunos supuestos conflictivos», Revista Derecho Privado, núm. 2 (2009), p. 56; M. Castilla Barea, Las intromisiones legítimas..., op. cit., p. 210, y A. PAÑos PéREZ, «El interés del menor como criterio...», op. cit., p. 824.

${ }^{28}$ Véase A. DE Lama Aymá, La protección de los derechos de la personalidad..., op. cit., pp. 223,274 y 275 . 
otras imágenes que pueda revelar su identidad —así, por ejemplo, fotografías de sus padres, su domicilio o colegio, junto a otras circunstancias identificativas- ${ }^{29}$. Y no sólo el nombre del menor, sino también el uso de otros datos, no acompañados de imágenes, que permitan identificarlo, como, por ejemplo, sus iniciales junto con su domicilio o el nombre de sus padres ${ }^{30}$. Obviamente, también la utilización conjunta de imágenes y nombre, e incluso la de imágenes «pixeladas» acompañadas de su nombre $\mathrm{u}$ otras circunstancias identificativas ${ }^{31}$. En todo caso, la premisa de la que se debe partir para concluir si hay una intromisión ilegítima es la identificación del menor. Si el tratamiento de las imágenes o datos no revela la identidad del menor —uso de fotografías «pixeladas» no acompañadas del nombre, divulgación de datos anónimamente- difícilmente se podrá apreciar la existencia de una intromisión ilegítima ${ }^{32}$.

Además, esta interpretación del término permite incluir la «difusión de información» en el apartado 3 del art. 4, pues el uso de imágenes o datos que permiten la identificación del menor puede tener lugar con ocasión de informaciones o noticias difundidas en un medio de comunicación ${ }^{33}$.

La utilización de estas imágenes y/o datos ha de tener lugar en «los medios de comunicación», pues se parte de un plus de peligrosidad que

${ }^{29}$ Véase la STS de 31 de mayo de 2011 que se pronuncia sobre la publicación en un diario de unas declaraciones (falsas) sobre unos hechos que afectaban a una menor, acompañadas de una fotografía en la que la menor aparecía de espaldas en brazos de su madre pero la madre aparecía de cara, señalándose además su nombre y apellidos. Al respecto, la sentencia indica que «aunque no se facilita el nombre, ni las iniciales de la niña, ni el domicilio, la sola identificación de la madre y el barrio donde la menor vive permite reconocer claramente a la afectada». Asimismo véase M. NAVARRo Michel, «Los derechos a la intimidad y propia imagen...», op. cit., pp. 62 y 63.

${ }^{30}$ Véanse ibid., pp. 62 y 63, y A. DE LAma Aymá, La protección de los derechos de la personalidad..., op. cit., p. 268.

31 Véase la STS de 28 de junio de 2004 que consideró desmesurada e innecesaria, a efectos informativos, la identificación de un menor como autor de un delito en un reportaje publicado en una revista en el que, contradictoriamente, la revista preservaba la imagen del menor tapando sus ojos con una franja blanca y facilitaba, en cambio, su nombre completo, entre otros datos.

32 En este sentido, García Garnica dispone que «para lesionar el honor no basta divulgar anónimamente datos injuriosos, sino ligados a un nombre, una imagen $\mathrm{u}$ otras circunstancias que permitan revelar la identidad del perjudicado». Cfr. M. C. GARCÍA GARNICA, El ejercicio de los derechos de la personalidad..., op. cit., p. 209. Asimismo véanse A. DE LAMA Aymá, La protección de los derechos de la personalidad..., op. cit., pp. 250, 274 y 275, y A. PAÑos PÉreZ, «El interés del menor como criterio...», op. cit., pp. 823 y 824.

33 Señala De Lama Aymá que este precepto no hace referencia al uso de información relativa al menor, pero ha de entenderse comprendida, aunque la difusión de información sin que se identifique al menor no sería intromisión ilegítima. Véase A. DE LAMA AymÁ, La protección de los derechos de la personalidad..., op. cit., p. 171. 
los medios de comunicación pueden entrañar para los derechos al honor, intimidad y propia imagen del menor, teniendo en cuenta que en estos medios es mucho mayor la difusión y con ello la gravedad de las consecuencias de la intromisión, es más elevada la frecuencia con la que se ataca a estos derechos para así atraer audiencia, y es también mayor la manipulación de la que pueden ser objeto los menores de edad, como señala la LOPJM en su Exposición de Motivos, por el deseo de popularidad o de ganar dinero ${ }^{34}$.

En el término «medios de comunicación» también habría que incluir aquellos supuestos en los que prensa, radio y televisión utilizan Internet como vía de difusión de sus contenidos. No tiene sentido dispensar un tratamiento diferente a una noticia publicada en un periódico digital o a un programa emitido en la web de una cadena de televisión, considerando además que por Internet la difusión es todavía mayor y, en consecuencia, el riesgo para los derechos al honor, intimidad e imagen del menor. El uso del blog o la red social con finalidad periodística estaría comprendido en estos supuestos ${ }^{35}$. Fuera de estos casos, habría además que incluir el uso (aun sin finalidad periodística) de páginas web, blogs, redes sociales u otras plataformas digitales en el término «medios de comunicación», teniendo presente que el peligro de manipulación del menor y la gravedad y frecuencia de las intromisiones se multiplican en estos supuestos, y que el propósito de la LOPJM es reforzar la protección de los derechos al honor, intimidad y propia imagen del menor ante estos riesgos ${ }^{36}$.

De acuerdo con los presupuestos del art. 4.3 LOPJM, cuando en un medio de comunicación se llevan a cabo actuaciones o intromisiones que conllevan un tratamiento de imágenes, nombre u otros datos que permitan la identificación del menor, aunque hayan sido consentidas por éste, no se elimina el carácter ilegítimo de las mismas si implican menoscabo de la honra o reputación del menor o son contrarias a los intereses del menor.

${ }^{34}$ Cfr. M. C. García Garnica, El ejercicio de los derechos de la personalidad..., op. cit., pp. 208 y 209.

${ }^{35}$ Véase bttp://www.poderjudicial.es/cgpj/es/Poder-Judicial/En-Portada/-Es-la-web-unmedio-de-comunicacion-.

${ }^{36}$ De Lama Aymá considera que el precepto se refiere a medios de comunicación o cualquier otra forma de difusión de la información, como Internet. Véase A. DE LAMA AyMÁ, La protección de los derechos de la personalidad..., op. cit., p. 223. Para Paños Pérez la alusión a los medios de comunicación debería ser interpretada en el sentido más amplio posible, entendiendo que la intromisión ilegítima puede tener lugar en el ámbito audiovisual o a través de otras vías como la red informática o la telefonía móvil. Véase A. PAÑos PéreZ, «El interés del menor como criterio...», op. cit., pp. 823. 
La «bonra y reputación» es parte del contenido tutelado por el derecho al honor, por lo que su menoscabo o lesión constituirá una intromisión ilegítima en el derecho al honor. Siguiendo al art. 4.3 LOPJM, aunque se haya consentido por el menor la conducta atentatoria contra su honor, ésta seguirá siendo ilegítima. De igual modo, cuando en un medio de comunicación, y dándose a conocer su identidad, el menor haya consentido una intromisión en su intimidad o imagen de la que resulten finalmente lesiones imprevistas o inesperadas en su derecho al honor, la intromisión tampoco perderá su carácter ilegítimo ${ }^{37}$.

En el mismo sentido, el art. 4.3 LOPJM haría también referencia a aquellos supuestos en los que el menor ha consentido una intromisión en su intimidad o imagen en un medio de comunicación, con la consiguiente identificación a través de imágenes o datos, que finalmente y de imprevisto resulta «contraria a sus intereses» ${ }^{38}$. El daño al interés del menor funciona como criterio que permite determinar o concluir cuándo una intromisión es ilegítima ${ }^{39}$.

A este respecto hay que tener en cuenta que el interés superior del menor persigue asegurar el respeto completo y efectivo de todos los derechos del menor, así como su desarrollo integral ${ }^{40}$. Para la interpretación y aplicación en cada caso del interés superior del menor, y poder concluir si éste ha resultado perjudicado, es necesario atender a los criterios incluidos en el art. 2.2 LOPJM, entre los que destacamos, a modo de ejemplo, la protección del desarrollo del menor y la satisfacción de sus necesidades emocionales y afectivas. Estos criterios deben ponderarse teniendo en cuenta la edad y madurez del menor, así como otras circunstancias recogidas en el art. 2.3 LOPJM o que puedan concurrir en el caso.

Por otro lado, no hay duda de que un ataque al honor es contrario a los intereses del menor y va en detrimento de su desarrollo; por ello entendemos que con esta referencia concreta al derecho al honor que con el tér-

${ }^{37}$ Cfr. M. J. SAntos Morón, «Menores y derechos de la personalidad...», op. cit., p. 77. Véase también A. PAÑos PÉREZ, «El interés del menor como criterio...», op. cit., p. 825. En contra véase M. C. García GarnicA, El ejercicio de los derechos de la personalidad..., op. cit., p. 211.

${ }^{38}$ Cfr. M. J. Santos Morón, «Menores y derechos de la personalidad...», op. cit., p. 78. En contra véase M. C. GARCíA GaRnICA, El ejercicio de los derechos de la personalidad..., op. cit., p. 211.

39 Véanse A. de Lama Aymá, La protección de los derechos de la personalidad..., op. cit., pp. 253 y 254, y A. PAÑos PÉREZ, «El interés del menor como criterio...», op. cit., p. 825.

40 Véase Exposición de Motivos de la Ley Orgánica 8/2015, de 22 de julio, de modificación del sistema de protección a la infancia y a la adolescencia, que ha reformado, entre otros, el art. 2 LOPJM. 
mino «honra o reputación» realiza el art. 4.3 LOPJM se quiere resaltar que siempre que se menoscabe o lesione al honor hay un perjuicio para el menor, y por ello esa conducta debe siempre reputarse como ilegítima ${ }^{41}$. Cuando el honor no resulte perjudicado será necesario atender en el caso si resultan afectados otros aspectos en detrimento del interés del menor.

Por tanto, el art. 4.3 LOPJM quiere expresar que el consentimiento prestado por el menor maduro no puede justificar estas intromisiones y deviene, por tanto, ineficaz, en la medida que de las mismas se derivan consecuencias imprevistas que lesionan el interés del menor, ya sea atacando su honor, como exponente de la dignidad, ya sea atacando otros aspectos en detrimento de su desarrollo. Y ello con el propósito de proteger al menor, teniendo presente la atracción que los medios ejercen sobre éste, que aparecen como una vía rápida y fácil de obtener dinero o notoriedad, lo que puede llevarlo a consentir situaciones de un alcance que compromete su interés con una gravedad y entidad mucho mayor de la que había previsto ${ }^{42}$.

Como ejemplo citamos el caso resuelto por la Sentencia del Tribunal Supremo de 17 de marzo de 2013, en el que un joven de diecisiete años accedió a responder a las preguntas realizadas por la reportera de una cadena de televisión cuando se encontraba en el gimnasio del hospital donde llevaba a cabo su rehabilitación para recuperarse de las graves lesiones que sufría, siendo posteriormente esta entrevista emitida en el informativo de la cadena con consecuencias inesperadas y contrarias al interés del menor, al realizarse junto a unas manifestaciones de la reportera que vinculaban las lesiones del menor al exceso de alcohol y de velocidad, y que daban lugar a especulaciones negativas que vulneraban su honor, según consideró el Tribunal Supremo ${ }^{43}$.

${ }^{41}$ Cfr. A. De Lama Aymá, La protección de los derechos de la personalidad..., op. cit., pp. 254 y 255. Asimismo véanse M. A. AsENSIO SÁnCHEZ, «Interés del menor y derecho a la intimidad, al honor y a la propia imagen», en J. Martínez-Torrón, S. Meseguer Velasco y R. PAlomino LozAno (coords.), Religión, matrimonio y Derecho ante el siglo XXI, vol. I, Religión y Derecho, Madrid, Iustel, 2013, p. 832, y A. PAÑOs PÉREZ, «El interés del menor como criterio...», op. cit., p. 825 .

42 Véase M. J. Santos Morón, «Menores y derechos de la personalidad...», op. cit., pp. 77 y 78.

43 Por el contrario, véase la STS de 26 de marzo de 2003 que consideró que no existía vulneración del derecho a la intimidad y propia imagen de un joven de catorce años en la entrevista emitida por un programa de televisión en la que el menor relataba la agresión sufrida a manos de otros jóvenes y en la que se revelaba su compleja situación personal y familiar. Hay que destacar que estos hechos ocurrieron con anterioridad a la LOPJM. Por ello opinamos que, teniendo en cuenta que la entrevista era desfavorable a los intereses del menor por la forma en la que se realizó (en el hospital donde se recuperaba de la agresión) y la visión negativa que se ofrecía del joven dando a conocer la complicada situación que 
Asimismo, en el supuesto resuelto por la ya mencionada Sentencia de la Audiencia Provincial de Sevilla (Sección 2. ${ }^{a}$ ) de 6 de febrero de 2013, en el que la entrevista que se realizó en televisión a una joven de catorce años, y que había sido consentida por ésta para aclarar su situación en un caso de máxima actualidad, se desarrolló de tal manera que se le terminó interrogando sobre otras cuestiones privadas sobre las que no quería hablar, ante las que se sintió mal, y que la convertían, aún más, en foco de atención mediática, todo ello de forma contraria al interés de la menor.

En resumen, la finalidad del art. 4.3 LOPJM es reforzar la protección del menor en este ámbito, lo que se justifica, como pone de manifiesto la antes citada Instrucción de la Fiscalía General del Estado núm. 2/2006, teniendo en cuenta que los ataques a estos derechos cuando el sujeto pasivo es un menor «no solamente lesionan el honor, intimidad y propia imagen, sino que además pueden perturbar su correcto desarrollo físico, mental y moral, y empañar, en definitiva, su derecho al libre desarrollo de la personalidad y a la futura estima social» (apartado 3.1) y que «la entidad del daño se multiplica exponencialmente cuando el ataque a los derechos del menor se realiza a través de un medio de comunicación» (apartado 3.4).

\section{LA INTERVENCIÓN DEL MINISTERIO FISCAL}

El art. 4 LOPJM preceptúa la intervención del Ministerio Fiscal en defensa del menor; en concreto, dispone en su apartado $2 .^{\circ}$ que «la difusión de información o la utilización de imágenes o nombre de los menores en los medios de comunicación que puedan implicar una intromisión ilegítima en la intimidad, honra o reputación del menor, o que sea contraria a sus intereses, determinará la intervención del Ministerio Fiscal», y en su apartado $4 .^{\circ}$ señala que «sin perjuicio de las acciones de las que sean titulares los representantes legales del menor, corresponde en todo caso al Ministerio Fiscal su ejercicio, que podrá actuar de oficio o instancia del propio menor o de cualquier persona interesada».

De acuerdo con el art. 4.2 LOPJM, el Ministerio Fiscal deberá intervenir cuando se produzcan intromisiones contrarias a la intimidad, honor

vivía, la solución del TS habría sido otra de haber resultado aplicable el art. 4.3 LOPJM. En el mismo sentido véanse M. NAVARRo MicheL, «Los derechos a la intimidad y propia imagen...», op. cit., p. 57, y M. J. SANTOS MORÓN, «Menores y derechos de la personalidad...», op. cit., pp. 77 y 78. 
o imagen de los menores en un medio de comunicación, en atención al mayor riesgo o peligro que los medios de comunicación pueden implicar para estos derechos del menor, como se ha puesto de manifiesto con anterioridad.

Continuando con el apartado 2. ${ }^{\circ}$ del art. 4 LOPJM, éste se refiere a la «difusión de información» y a la «utilización de imágenes o nombre». Según hemos concluido anteriormente, el apartado 3..$^{\circ}$ del art. 4 LOPJM con la expresión «utilización de las imágenes o nombre de los menores» quiere hacer referencia a toda utilización de imágenes o datos que permite identificar al menor o dar a conocer su identidad en el medio de comunicación, y esta misma interpretación del término es la que hay que hacer en el apartado $2{ }^{\circ}$ Con ello se alude a la identificación como presupuesto necesario de una intromisión ilegítima, pues no se lesiona el derecho al honor o a la intimidad si los datos se divulgan preservando el anonimato del menor, y tampoco el derecho a la imagen en una fotografía del menor con la cara «pixelada». Ahora bien, cuando la identidad del menor se revele a través de su imagen o nombre, resultará afectado el derecho a la imagen, pudiendo resultar también lesionados el honor o la intimidad ${ }^{44}$.

Respecto a la «difusión de la información», el término comprende aquellos supuestos en los que los medios de comunicación dan a conocer noticias o informaciones en las que puede estar involucrado un menor o que puedan tener alguna relación con un menor. Para apreciar la existencia de una intromisión ilegítima, el medio de comunicación tiene que haber difundido esas informaciones dando a conocer la identidad del menor, ya sea a través de su imagen o nombre, o bien incluyendo otras imágenes o datos (domicilio con iniciales del menor, nombre de los padres, etc.) que permitan identificarlo. La LOPJM busca así que se preserve el anonimato del menor al divulgar esas noticias para evitar que se lesionen sus derechos ${ }^{45}$.

Por tanto, cuando en un medio de comunicación se revela o da a conocer la identidad del menor, ya sea con motivo de la transmisión de una

44 Señala O'Callaghan Muñoz que la LOPJM emplea términos equívocos, pudiendo la expresión «utilización de imágenes y nombre» referirse a un atentado al derecho a la imagen o simplemente a la identificación del menor en las intromisiones al honor y a la intimidad. Véase X. O'CAllaghan Muñoz, «Personalidad y derechos de la personalidad...», op. cit., p. 1250.

${ }^{45}$ Véanse X. O'Callaghan Muñoz, «Personalidad y derechos de la personalidad...», op. cit., p. 1250; M. J. SANTOS MORÓN, «Menores y derechos de la personalidad...», op. cit., p. 76, y A. PAÑos PÉREZ, «El interés del menor como criterio...», op. cit., p. 823. Véase también la ya citada Instrucción de la Fiscalía General del Estado núm. 2/2006 (apartado 6.5). 
noticia en la que esté involucrado («difusión de la información») o de otras circunstancias (por ejemplo, un programa de televisión en el que participa), conculcándose su derecho a la intimidad o al honor, o a sus intereses, deberá intervenir el Ministerio Fiscal.

La LOPJM sólo alude a las intromisiones ilegítimas a la intimidad y el honor («honra y reputación»); no obstante, hay que entender incluidas las intromisiones contrarias en la propia imagen cuando se utilicen imágenes del menor como elemento identificador ${ }^{46}$. Asimismo, el art. 4.2 LOPJM comprendería tanto intromisiones inconsentidas como aquellos supuestos en los que la ilegitimidad viene dada por existir un consentimiento viciado o porque, aun consentida la intromisión, concurren los presupuestos ya estudiados en el apartado 3 del art. 4. Por otro lado, el perjuicio a los intereses del menor funciona como criterio delimitador de la existencia de intromisiones ilegítimas, como ya hemos estudiado ${ }^{47}$.

A este respecto, la intervención del Ministerio Fiscal consistirá en instar de inmediato las medidas cautelares y de protección previstas en la Ley y solicitar las indemnizaciones que correspondan por los perjuicios causados (art. 4.2 LOPJM). Pese a la inconcreción de la LOPJM, habrá que atender a las medidas y a la reclamación de los perjuicios previstos en el art. 9.2 de la LO $1 / 1982^{48}$.

Asimismo, entre las medidas de protección que el fiscal deberá instar de inmediato se encuentra el ejercicio de las acciones al que alude el art. 4.4 LOPJM. Novedosamente, en el art. 4.4 LOPJM la legitimación del fiscal para accionar en defensa de los derechos al honor, intimidad y propia imagen se configura de forma directa y autónoma, no subsidiaria, pues su actuación no está supeditada a la falta de representantes legales del menor. Al Ministerio Fiscal se le impone el deber de ejercitar estas acciones, de oficio o a instancia de parte, cuando concurran los presupuestos del art. 4.2 LOPJM, es decir, cuando se produzcan intromisiones ilegítimas en el honor, intimidad o propia imagen del menor en un medio de comunicación. Todo ello se subraya en la arriba citada Instrucción de la Fiscalía General del Estado núm. 2/2006 (apartados 4 y 14).

\footnotetext{
46 Véase X. O’Callaghan Muñoz, «Personalidad y derechos de la personalidad...», op. cit., p. 1250.

47 Véase A. De Lama Aymá, La protección de los derechos de la personalidad..., op. cit., pp. 253 y 254, y A. PAÑos PÉREZ, «El interés del menor como criterio...», op. cit., p. 825.

48 Véanse X. O'Callaghan Muñoz, «Personalidad y derechos de la personalidad...», op. cit., p. 1250, y L. Díez-Picazo y A. Gullón, Sistema de Derecho Civil, op. cit., p. 345. Como ejemplo de estas medidas de orden cautelar véase J. M. DE LA RosA CoRTINA, «El derecho al honor, intimidad y propia imagen...», op. cit., p. 47.
} 
En todo caso, hay que tener presente que el art. 4.4 LOPJM confiere el ejercicio de las acciones de defensa de los derechos al honor, intimidad y propia imagen del menor tanto al fiscal como a los representantes legales; idea que se repite en el art. 4.5 LOPJM al disponer que los padres o tutores $y$ los poderes públicos (entre los que se encuentra el Ministerio Fiscal) respetarán estos derechos y los protegerán frente a posible ataques de terceros ${ }^{49}$. Ahora bien, la manera en la que se ha articulado la legitimación del fiscal en el art. 4 LOPJM muestra una preferencia por la tutela pública de estos derechos, y en este sentido la Instrucción de la Fiscalía General del Estado núm. 2/2006 (apartado 4) afirma que «subyace sin duda en la Ley un interés en que la protección de los derechos de los menores trascienda o desborde al deber de protección de los titulares de la patria potestad, erigiéndose en una prestación pública, en tanto que se configura como una obligación para un órgano estatal».

A este respecto, algunos autores opinan que la legitimación del Ministerio Fiscal debería haberse dispuesto de forma subsidiaria por estar los representantes legales en mejores condiciones para valorar el interés de los menores y para evitar el desplazamiento de la autoridad de los padres o tutores y de la autonomía del propio menor ${ }^{50}$.

Por el contrario, entendemos que con este sistema la LOPJM quiere reforzar la protección del menor, de manera que el fiscal pueda intervenir en defensa de los derechos lesionados de éste cuando la participación del menor en el medio haya sido auspiciada por sus propios padres o tutores o cuando los representantes legales no reaccionen adecuadamente, incluso en aquellos casos en los que el menor maduro haya consentido su participación ${ }^{51}$. Sin embargo, ello no es obstáculo para que el fiscal pondere su intervención en atención a las circunstancias del caso, pues, como señala la Instrucción de la Fiscalía General del Estado núm. 2/2006 (apartado 4), «un arma de tan grueso calibre debe utilizarse con mesura, ponderando los intereses en conflicto».

Por ello, la Instrucción de la Fiscalía General del Estado núm. 2/2006 (apartado 4) contiene una serie de pautas o directrices que sirven de guía a

${ }^{49}$ Cfr. X. O’Callaghan Muñoz, «Personalidad y derechos de la personalidad...», op. cit., p. 1250.

50 Véanse M. C. García GaRnica, El ejercicio de los derechos de la personalidad..., op. cit., pp. 215 y 216; M. NAVARRO MiCHEL, «Los derechos a la intimidad y propia imagen...», op. cit., pp. 56-58, y L. DíEz-PiCAZo y A. Gullón, Sistema de Derecho Civil, op. cit., p. 345 .

51 Véase A. DE Lama Aymá, La protección de los derechos de la personalidad..., op. cit., p. 173. Asimismo véanse J. M. DE LA ROSA CORTINA, «El derecho al honor, intimidad y propia imagen...», op. cit., p. 34, y M. CASTILLA BAREA, Las intromisiones legítimas..., op. cit., p. 217. 
los fiscales, que les ayuda a valorar los intereses en conflicto y a decidir, en consecuencia, cuándo tienen que ejercitar estas acciones en defensa de los derechos al honor, intimidad y propia imagen de los menores. Así, señala que: «Habrá de ser excepción la intervención autónoma del fiscal cuando el afectado tenga progenitores en pleno uso de las facultades inherentes a la patria potestad, y que - sin que concurra conflicto de intereses con el menor- sean contrarios a que se entablen acciones en defensa del mismo. Esta excepción habrá de estar basada en una cualificada intensidad lesiva de la intromisión».

Y en relación a los supuestos de intromisiones ilegítimas consentidas por menores con suficiente madurez, indica que «aunque la Ley Orgánica 1/96 debilita la eficacia justificadora del consentimiento del menor (art. 4.3, inciso final), la concurrencia del mismo debe sopesarse en cada caso a la hora de concretar si se ha producido un perjuicio para sus intereses. No debe olvidarse que la propia Exposición de Motivos de la Ley considera que la mejor forma de garantizar social y jurídicamente la protección a la infancia es promover su autonomía como sujetos [...] No puede, por tanto, asumirse una interpretación conforme a la cual se elimine radicalmente la facultad de los menores maduros de ejercitar los derechos de la personalidad, tan ligados al libre desarrollo de la misma». Y, por todo ello, concluye que «habrá de oírse al menor antes de decidir sobre el ejercicio de acciones. Frente a una voluntad decididamente contraria del menor maduro no procederá ejercitar acciones en su nombre salvo que así lo requiera la propia entidad de la lesión de sus derechos o salvo que tras la audiencia del menor se llegué a la conclusión de que carece de madurez para autodeterminarse en la materia» ${ }^{52}$.

Observamos que la mencionada Instrucción de la Fiscalía núm. 2/2006 es consciente del «choque» que se produce entre la autonomía del menor y la intervención del fiscal como garante de sus derechos en aquellos casos en los que la intromisión ha sido consentida por un menor con suficiente madurez, y por ello establece estas pautas a seguir por los fiscales.

Por tanto, antes de actuar, el fiscal deberá concluir, en primer lugar, si se cumplen los presupuestos del art. 4.3 LOPJM, es decir, si se trata de una intromisión consentida por un menor maduro que se ha llevado a cabo en un medio de comunicación, dándose a conocer la identidad de este menor, y que resulta contraria a su honor o intereses. Y a continuación el fiscal deberá concluir si el interés del menor se protege ejerciendo las acciones en defensa de los derechos al honor, intimidad o propia imagen

\footnotetext{
52 La cursiva es nuestra.
} 
del mismo, o, por el contrario, este interés se protege no interviniendo y respetando las decisiones que el menor ha tomado en ejercicio de su autonomía. Para ello, teniendo presentes los criterios recogidos en el art. 2.2 LOPJM, el fiscal habrá de valorar en qué medida resulta afectado el desarrollo del menor en el futuro y atender a la edad y madurez del menor, la gravedad de la lesión, el alcance de la difusión y demás circunstancias del caso - art. 2.3 LOPJM-.

En este sentido señalamos como ejemplo la actuación del Ministerio Fiscal interponiendo demanda ante el Juzgado de Primera Instancia núm. 1 de Sevilla por intromisión ilegítima contra los derechos a la intimidad y a la propia imagen de una menor de acuerdo con el art. 4 LOPJM, y que dio lugar a la Sentencia de 11 de enero de 2011 que estimaba las pretensiones del fiscal ${ }^{53}$ y que fue finalmente confirmada por la Sentencia de la Audiencia Provincial de Sevilla (Sección 2. ${ }^{a}$ ) de 6 de febrero de 2013, ya mencionada más arriba. Si bien la joven de catorce años había consentido que se la entrevistara, en los programas televisivos en los que se produce la intromisión, para aclarar su situación respecto a unos hechos de máxima actualidad, el interés inicial de su entrevista termina siendo una excusa para interrogarle sobre otras cuestiones personales sobre las que no quería hablar, y ante las cuales la joven se siente incómoda e incluso se echa a llorar. Además, esta participación la convertía aún más en foco de atención de los medios de comunicación y de la opinión pública, por tener lugar con ocasión de unos acontecimientos de fuerte impacto social y mediático, y por tratarse de programas televisivos de amplia difusión al emitirse en una cadena de ámbito nacional. Todo ello agravaba la entidad de la lesión en sus derechos y, en consecuencia, hacía necesaria esta actuación del fiscal ${ }^{54}$.

Por otro lado, podría objetarse que el Ministerio Fiscal debería haberse abstenido de intervenir, ya que podía suscitar opiniones en demérito de la menor que se reclamara una indemnización en su nombre por atacarse su intimidad e imagen cuando la joven había concedido voluntariamente estas entrevistas e incluso podría haber solicitado, junto con su madre, una retribución por las mismas ante el tirón mediático de los hechos con los que estaba relacionada ${ }^{55}$. En respuesta a esta objeción nos

\footnotetext{
53 Salvo en lo referente al quantum indemnizatorio.

54 En sentido similar véase J. R. DE VERDA y BEAMONTE, «Resarcimiento del daño moral por intromisiones consentidas en el derecho a la propia imagen de menores (en relación al caso Marta del Castillo)», Diario La Ley, núm. 7.171 (2009), p. 1660.

55 De Verda y Beamonte señala que la paradoja del caso radica en que la menor a la que se pretende proteger consintió voluntariamente la captación de su imagen e incluso se
} 
acogemos a las consideraciones vertidas por la Audiencia Provincial de Sevilla (Sección 2. ${ }^{a}$ ) en la Sentencia de 6 de febrero de 2013, que dispone que «a pesar de haber firmado e incluso haber solicitado la menor o su madre algún beneficio económico, ello no legitimaría a los demandados a poder utilizar sin cortapisa ni límite la entrevista de la menor o la vulneración del derecho a la intimidad y a la propia imagen», y, asimismo, a las palabras de la Instrucción de la Fiscalía General del Estado núm. 2/2006 (apartado 4), cuando señala que «las acciones del fiscal en protección de los derechos del menor contra un medio de comunicación tienen un valor que transciende el caso concreto para generar efectos preventivos generales, previniendo comportamientos similares por otros medios e irradiando mecanismos inhibitorios erga omnes». Es decir, la lesión en los derechos de la menor existía por la forma en la que se había desarrollado la entrevista, independientemente de su carácter voluntario e incluso oneroso, y en este sentido era conveniente la intervención del Ministerio Fiscal ejercitando las acciones oportunas en defensa de los derechos vulnerados y reclamando la pertinente indemnización, que no pretendía premiar a la joven, sino la reparación del grave perjuicio que se causó a sus derechos ${ }^{56}$. Además, al estimarse las pretensiones del fiscal en defensa de los intereses de la menor, tanto en primera instancia como en la sentencia de la Audiencia que la confirma ${ }^{57}$, la actuación del fiscal, como señala la Instrucción núm. 2/2006, tiene efectos inhibitorios que previenen futuros comportamientos de este tipo en los medios.

había especulado con la posibilidad de que la madre de la joven cobrara por la entrevista, y el autor subraya el siguiente interrogante: ¿con el pretexto de indemnizar la intromisión en un derecho de la personalidad de la menor, no se le estará premiando económicamente por una intervención morbosa, en la que con el fin de aumentar la audiencia de la cadena se relatan hechos relativos a un delito de gran repercusión mediática? Véase ibid., p. 1657.

56 De Verda y Beamonte también valora positivamente la actuación del Ministerio Fiscal en este supuesto, pues considera que, aun consintiendo la menor la utilización de su imagen, de ello resultó un perjuicio objetivo para ésta, al verse relacionada con unos hechos de relevancia penal y de gran trascendencia social. Véase ibid., p. 1660.

57 Es cierto que la sentencia de primera instancia estimó las pretensiones del fiscal, salvo en lo referente al quantum indemnizatorio, y estableció una indemnización con una cuantía inferior a la que solicitaba el Ministerio Fiscal, argumentando que de esta forma la indemnización cumplía la finalidad reparadora pretendida, en lugar de propiciar un fin distinto. Pero ello no es impedimento para considerar que la actuación del fiscal, interponiendo las acciones de tutela de los derechos vulnerados y reclamando la correspondiente indemnización, era acertada. Cuestión aparte es la de la conveniencia del quantum indemnizatorio. 


\section{CONCLUSIONES}

La protección de los derechos al honor, intimidad y propia imagen del menor maduro oscila, fundamentalmente, entre el art. 3 de la LO 1/1982 y el art. 4 LOPJM.

Por un lado, conforme al art. 3.1 de la LO 1/1982, el consentimiento que elimina el carácter ilegítimo de las intromisiones en el honor, intimidad y propia imagen del menor deberá prestarse por el propio menor cuando sus condiciones de madurez lo permitan, es decir, cuando tenga la suficiente capacidad para comprender las consecuencias de sus actos y decidir por sí mismo, lo que dependerá del acto en concreto que vaya a consentir y de su evolución o desarrollo personal. El art. 3.1 de la LO 1/1982 confiere al consentimiento del menor maduro un tratamiento análogo al de los mayores de edad, que implica, en definitiva, reconocer al menor un ámbito de autonomía y decisión propio que debe ser respetado si queremos proteger de forma adecuada su interés superior.

Por otro lado, el art. 4.3 LOPJM establece la ineficacia del consentimiento del menor, aun con suficiente madurez, prestado a una intromisión en sus derechos al honor, intimidad o propia imagen, si bien no con carácter general, sino sólo cuando concurren las circunstancias recogidas por este precepto, es decir, cuando la intromisión tenga lugar en un medio de comunicación y sea contraria al honor o intereses del menor. Y ello con el propósito de reforzar la protección del menor en este ámbito, teniendo en cuenta el riesgo de manipulación de la que en los medios de comunicación pueden ser objeto los menores que, movidos por razones de fama o por dinero, llegan a consentir situaciones de las que se derivan consecuencias inesperadas que perjudican su interés con una alcance mucho mayor del que habían previsto. Esta regulación del art. 4.3 LOPJM se justifica, además, por la entidad que una lesión en estos derechos tiene, en la medida que un ataque al derecho al honor, intimidad o propia imagen puede también afectar de forma desfavorable a la evolución del menor y al libre desarrollo de su personalidad.

Asimismo, y de acuerdo con esta intensificación de los niveles de protección de los menores, se preceptúa en el art. 4.2 LOPJM la intervención de Ministerio Fiscal, que deberá reaccionar, ante una intromisión ilegítima en los derechos al honor, intimidad y propia imagen del menor en los medios de comunicación, ejercitando las acciones en defensa de estos derechos a las que alude el art. 4.4 LOPJM, incluso en aquellos supuestos 
en los que la intromisión haya sido consentida por un menor con suficiente madurez. No obstante, en estos supuestos de intromisiones consentidas por un menor maduro, el fiscal antes de actuar deberá ponderar todas las circunstancias concurrentes en el caso y concluir si el interés superior del menor requiere el respeto a sus decisiones, sobre todo cuando la voluntad del menor sea decididamente contraria a la intervención del fiscal, o, por el contrario, la protección de su interés exige que el fiscal intervenga ejercitando las acciones pertinentes, especialmente cuando la importancia de la lesión así lo aconseje, por resultar gravemente afectado el desarrollo del menor.

\section{BIBLIOGRAFÍA}

Albaladejo, M., Derecho Civil. I. Introducción y Parte General, Madrid, Edisofer, 2009.

Asensio SÁnchez, M. A., «Interés del menor y derecho a la intimidad, al honor y a la propia imagen», en J. Martínez-Torrón, S. Meseguer Velasco y R. PaloMINO LOZANO (coords.), Religión, matrimonio y Derecho ante el siglo XXI, vol. I, Religión y Derecho, Madrid, Iustel, 2013, pp. 815-833.

Cabezuelo Arenas, A. L., Derecho a la intimidad, Valencia, Tirant lo Blanch, 1998.

Castilla BAREA, M., Las intromisiones legitimas en el derecho a la propia imagen, Cizur Menor, Aranzadi, 2011.

De la Rosa Cortina, J. M., «El derecho al honor, intimidad y propia imagen de los menores. Perspectivas en Derecho civil, penal y en reforma de menores», Revista del Poder Judicial, núm. 72 (2003), pp. 11-58.

De Lama Aymá, A., La protección de los derechos de la personalidad del menor de edad, Valencia, Tirant lo Blanch, 2006.

De Verda y Beamonte, J. R., «Resarcimiento del daño moral por intromisiones consentidas en el derecho a la propia imagen de menores (en relación al caso Marta del Castillo)», Diario La Ley, núm. 7.171 (2009), pp. 1657-1660.

Díez-Picazo, L., y Gullón, A., Sistema de Derecho Civil, vol. I, Madrid, Tecnos, 2012.

Garberí Llobregat, J., Los procesos civiles de protección del honor, la intimidad y la propia imagen, Barcelona, Bosch, 2007.

García GaRnica, M. C., El ejercicio de los derechos de la personalidad del menor no emancipado, Cizur Menor, Aranzadi, 2004.

Grimalt Servera, P., La protección civil de los derechos al honor, a la intimidad y a la propia imagen, Madrid, Iustel, 2007.

Lacruz Berdejo, J. L., et al., Elementos de Derecho Civil. I. Parte General, vol. II, Personas, Madrid, Dykinson, 2010. 
Lasarte, C., Principios de Derecho Civil, t. I, Parte General y derecho de la persona, Madrid, Marcial Pons, 2010.

Navarro Michel, M., «Los derechos a la intimidad y propia imagen del menor de edad. Algunos supuestos conflictivos», Revista Derecho Privado, núm. 2 (2009), pp. 47-74.

O’Callaghan Muñoz, X., «Personalidad y derechos de la personalidad (honor, intimidad e imagen) del menor, según la Ley de Protección del Menor», La Ley: Revista jurídica española de doctrina, jurisprudencia y bibliografía, núm. 4 (1996), pp. 1247-1251.

PAÑos PÉREZ, A., «El interés del menor como criterio para determinar la ilegitimidad de la intromisión en los derechos del honor, la intimidad y la propia imagen», Revista Actualidad Civil, núm. 8 (2012), pp. 811-835.

SAntos Morón, M. J., «Menores y derechos de la personalidad. La autonomía del menor», Anuario de la Facultad de Derecho de la Universidad Autónoma de Madrid, núm. 15 (2011), pp. 63-93. 